\title{
ISTORIJA
}

\section{MAŽASIS SEIMAS LIETUVOS PARLAMENTO ISTORIJOJE}

\author{
Prof. Habil. DR. Mindaugas Maksimaitis
}

Mykolo Romerio universiteto Teisés fakultetas

Teisés filosofijos ir istorijos katedra profesorius-emeritas

Mykolas Romeris University, Faculty of Law Departament of Philosophy and History of Law Ateities g. 20, LT-08303 Vilnius El.paštas mindaugasmaksimaitis@mruni.eu

\section{Santrauka}

Straipsnyje aptariamos politinès ir teisines Mažojo Seimo, tapusio ryškiu epizodu Lietuvos parlamentarizmo raidoje, atsiradimo prielaidos, analizuojamas jo sudarymas, veikla ir pasiekti rezultatai.

Mažojo Seimo isteigimas ir veikla sudare galimybe i Steigiamaji Seimą išrinktiems autoritetingiausiems visuomenès nariams įsijungti i tiesioginę veikla mobilizuojant krašto pajègas kovai prieš lenku agresiją. Tai padejo išvengti Steigiamojo Seimo, didžiaja laiko dali lygiagrečiai su pagrindiniu valstybès istatymu rengimu skyrusio einamiesiems parlamentines veiklos klausimams spręsti, darbo trukdžiu.

Reikšminiai žodžiai: parlamentarizmas; Lietuvos Steigiamasis Seimas; Mažasis Seimas. 


\section{Ivadas}

Mažojo Seimo sudarymas ir veikla reiškia nors ir neilgą, bet ganètinai ryšku ịvykị Steigiamojo Seimo ir apskritai Lietuvos parlamentarizmo raidoje. Todèl natūralu ir suprantama, kad literatūroje apie ji užsimenama beveik kaskart, prisilietus prie Lietuvos Steigiamojo Seimo istorijos problematikos. Tačiau darbų, specialiai skirtų Mažojo Seimo organizacijai, veiklai ar reikšmei, deja, beveik nerasime. Truputi detalesnị teisinị šios parlamentinès institucijos vertinimą savo darbuose, beje, daugiausia skelbtuose išeivijoje, yra atlikę tik Mykolas Romeris ${ }^{1}$, iš dalies - Vanda Daugirdaitè-Sruogienè, Domas Krivickas, Pranas Pauliukonis, Pranas Viktoras Raulinaitis, Liudvikas Šmulkštys, Vladas Viliamas². Kiek išsamiau apie Mažąji Seimą daugiau nei prieš dešimtmetị yra rašęs šių eilučių autorius ${ }^{3}$.

Mažojo Seimo organizacijos ir veiklos tyrimą apsunkina tai, kad, skirtingai nuo Steigiamojo Seimo plenumo, jam visuomenès buvo skirtas gerokai mažesnis dèmesys jau vien dèl to, kad savo misiją jis vykdè itin dramatiškų Lietuvai įvykių fone, be to, trūksta medžiagos: nėra išlikusių jo posėdžių stenogramų (jeigu tokios apskritai buvo), veiklą menkiau aprašė dar negausi ano meto spauda, o jo archyvas apskritai nežinomas.

Straipsnio tikslas - remiantis teisès aktais, spaudos kronika, kuklia ¿vvairiose bylose išsibarsčiusia archyvine medžiaga ir jau esama literatūra, istoriniu teisiniu požiūriu ịvertinti Mažojo Seimo instituciją, atskleisti jo vaidmeni Lietuvos parlamentarizmo raidoje.

1 [Römeris] Rèmeris, M. Lietuvos konstitucinès teisès paskaitos. Vilnius: Mintis, 1990, p. 114-116.

2 Daugirdaitè-Sruogienė, V. Lietuvos Steigiamasis Seimas. New York, 1975; Kr[ivickas], D. Mažasis Seimas. Lietuviu enciklopedija. T. 18. Boston, 1959; Pauliukonis, P. Lietuvos valstybės pagrindus tiesiant. Aidai. 1970, Nr. 5; Raulinaitis, P.V. Parlamentarizmas: istoriniai-teoretiniai parlamentinès tvarkos bruožai. Klaipèda, 1925; Šmulkštys, L. Žvilgsnis ị Steigiamojo Seimo istoriją. Seja. 1960, Nr. 2; Viliamas, V. Lietuvos Seimai ir jų grupinè diferenciacija. Tévynés sargas. 1954, Nr. 1(11).

3 Maksimaitis, M. Mažasis Seimas - ryškus epizodas Lietuvos parlamentarizmo raidoje. Jurisprudencija. T. 17(9) (2000). 


\section{Politinès Mažojo Seimo įsteigimo priežastys}

Jaunai nepriklausomai Lietuvos valstybei 1920 m. rugpjūčio mèn. atgavus istorinę sostinę Vilnių, buvo sužibusi viltis pagaliau pradèti taikų gyvenimą, lauktą nuo pat Didžiojo karo pradžios. Tačiau taip neatsitiko: prancūzams padedant sustiprèjusi Lenkija ankstyvą rudenį èmè stumti atgal Varšuvą spejjusią pasiekti rusų Raudonąją armiją ir, nepaisydama Lietuvos Vyriausybės paskelbto neutraliteto, Gardino-Augustavo ruože sudavė keletą skaudžių smūgių jaunai jos kariuomenei. Ir nors spalio $7 \mathrm{~d}$. Suvalkuose, dalyvaujant Tautų Sąungos stebėtojams, pasirašyta sutartis, kuria Lenkija pripažino Lietuvos teises ị Vilnių, jau po dviejų dienų ši sutartis buvo šiurkščiai sulaužyta - Liucijano Želigovskio legionai užgrobẻ Vilnių ir èmẻ brautis gilyn ị Lietuvos teritoriją.

Vietoj lauktos ramybès Lietuvoje staiga susidarè nepaprastai grèsminga padètis, sukèlusi tautoje retą dvasini pakilimą ir susitelkimą. Gyventojai buvo kupini ryžto apginti neseniai atgautą ir jau brangia kraujo kaina apgintą savo krašto nepriklausomybę. I rinkimosi punktus gausiai patraukè savanoriai, ištuštėjo gimnazijų klasės, sodžiaus jaunimas balnojo tèvų žirgus ir būrèsi ì formuojamą raitelių „Geležinio vilko" pulką. Kūrèsi visuomeniniai Lietuvos gynimo komitetai, kariams ị frontą buvo siunčiami gyventojų suaukoti šilti drabužiai, maistas, renkamos aukos ginklams. Žmonès atsisakydavo vertingesnio daikto, šeimyninių relikvijų - auksinių ir sidabrinių žiedų, grandinèlių, kryželių.

O Kaune tuo metu savo kasdienį darbą dirbo Steigiamasis Seimas, visuomenèje pagarbiai tituluojamas Lietuvos šeimininku. Jame posèdžiavo šimtas dvylika daugiausia jaunų (tik aštuoni atstovai turejo per 50, o dvidešimt devyni dar nebuvo sukakę ir 30 metų amžiaus), sveikų ir energingų žmonių. Nors jame tvyrojo nerimas, iš tribūnos ir kuluaruose aidejo nerimastingi balsai, o keletas Steigiamojo Seimo narių, 
tiesiogiai ịsitraukusių ị valstybės gynimo akcijas, laikinai buvo atleisti nuo prievolès lankytis posėdžiuose ${ }^{4}$, apskritai jame vyko ịprastas parlamentinis darbas ir, iš šalies pažvelgus, šis vaizdas tarsi disonavo su bendra krašto atmosfera.

Steigiamajame Seime posėdžiavo įvairių socialinių sluoksnių, skirtingų ideologinių ir politinių pakraipų žmonès, bet juos jungė siekis išsaugoti ir sutvirtinti Lietuvos valstybę ir jos nepriklausomybę, noras padaryti dèl šalies visa, kas buvo įmanoma kiekvieno jų jègoms. Itempta ir greitai besikeičianti situacija reikalavo tokių pat greitų ir tikslių sprendimų, o Steigiamojo Seimo pilnaties posèdžiai, vykę laikantis formalios parlamentinès procedūros, buvo sunkiai pritaikomi skubiems sprendimams priimti. Ne visais atvejais karo sąlygomis buvo naudingas Seimo veiklos viešumas. Bet kada galèjo kilti sunkumų surenkant posėdžių kvorumui reikalingą atstovų skaičių ${ }^{5}$.

Susiklosčiusi padètis priminè dar taip nesenus 1919-uosius, kai vos spejjusius išsikalti Lietuvos laisvès daigus mėgino išrauti bolševikai ir kiti jos nedraugai, o pradejusioje organizuotis valstybeje, kaip to reikalavo 1918 metų Laikinosios Konstitucijos Pamatiniai Dėsniai, dominuojančią padètị užèmusiai Valstybès Tarybai su kolektyvine jos pačios ir valstybės vadovybe ėmė trūkti lankstumo. Tuomet konstitucinis įstatymų leidèjas - ta pati Valstybès Taryba - ryžosi laikinai užleisti savo funkcijas vykdomosios valdžios institucijoms ir joms netrukdyti: siekdama išvengti ilgokos ir sudètingos įstatymų leidybos procedūros, Taryboje jau spejusios igyti tipiškas parlamentines formas, $1919 \mathrm{~m}$. sausio mèn. įstatymų leidybos teise ji pasidalijo su Ministrų kabinetu' ${ }^{6}$, o balandžio 4 d. peržiūrejjo Laikinosios Konstitucijos Pamatinius Dėsnius $^{7}$, ị pirmąją vietą pagrindinių valstybès įstaigų sistemoje iškeldama

4 Blažytė-Baužienė, D., Tamošaitis, M., Truska, L. Lietuvos Seimo istorija: XX-XXI a. pradžia. Vilnius: „Baltų lankų“ leidyba, 2009, p. 76.

5 Laučka, J.B. Lietuvos parlamentinè santvarka. Tèvynés sargas. 1970, Nr. 1, p. 114.

6 Laikinosios Lietuvos Valstybės Konstitucijos papildas. Laikinosios Vyriausybés žinios (toliau - LVŽ). 1919, Nr. 4-41.

7 Lietuvos Valstybès Laikinosios Konstitucijos Pamatiniai Désniai. Kaunas, [1919]. 
vykdomąją valdžią su kolegialų Valstybės Tarybos Prezidiumą pakeitusiu vienasmeniu Valstybès Prezidentu priešakyje. Prezidentui suteikta išimtinè teisè šaukti Valstybès Tarybos sesijas ir jas paleisti, o Tarybai neposėdžiaujant - pačiam leisti ịstatymus, priimtus Ministrų kabineto. Igyvendindama šias Konstitucijos nuostatas, Valstybės Taryba Prezidentu tuomet buvo išrinkusi vieną iš Tautos pažangos partijos lyderių Antaną Smetoną, kuris per pusę metų, iki pat spalio mèn., Valstybės Tarybos nẻ karto nesušaukè, užtikrindamas karo sąlygoms būtiną valdymo operatyvumą, padejjusị „išgelbèti kraštą nuo pražūties" ${ }^{\text {“8 }}$.

Tautos pažanga išmoko šią pamoką. Šios partijos, rinkẻjų valia neturinčios atstovų Steigiamajame Seime, vadovybė 1920 m. spalio 14 d. paviešino rezoliuciją, rekomendavusią to meto valdantiesiems, 1920 metų Laikinąja Lietuvos Valstybès Konstitucija ${ }^{9}$ ịtvirtinusiems parlamentinę sistemą su reprezentacinio pobūdžio galiomis besinaudojančiu Respublikos Prezidentu, realiai net neišrinktu, laikinai tenkinantis jo pareigu pavedimu Steigiamojo Seimo Pirmininkui, nedelsiant išrinkti Valstybės Prezidentą (pareigybès pavadinimas šiuo atveju paskolintas iš 1919 metų konstitucinio akto, gal net viliantis joje išvysti tą pačią personą) ir suteikti jam „plačias teises Valstybės vidaus tvarkymo ir nuo svetimų priešininkų gynimo srity“. Rezoliucijoje reikalauta Prezidentui pavesti ginkluotąsias pajègas ir suteikti veto teisę leidžiamiems įstatymams. Pasak rezoliucijos rengejjų, išliekant pavojaus valstybei grèsmei, Vyriausybè turi gauti galimybę veikti greičiau, savarankiškiau ir griežčiau, o Seimas privalantis posėdžiauti ne nuolat, o tik „tam tikrais svarbiais reikalais“ ir tik Prezidentui pašaukus ${ }^{10}$.

Tačiau dabar padètis buvo ne tokia kaip 1919-aisiais. Steigiamasis Seimas buvo pašauktas reikšti suverenines Lietuvos galias, todèl, rūpindamasis visą politinę valdžią išlaikyti savo rankose, nesijautè tu-

8 [Smetona, A.] Lènas. Kritika ir polemika. Tauta. 1920, spalio 29 (Nr. 54).

9 Laikinoji Lietuvos Valstybès Konstitucija. LVŽ. 1920, Nr. 37-407.

10 Tautos pažangos partijos rezoliucija dèl einamojo momento. Tauta. 1920, spalio 16 (Nr. 52). 
rintis teisę trauktis ir tautos suteiktą mandatą bent laikinai perleisti Vyriausybei, kaip panašiomis aplinkybèmis buvo padariusi Valstybės Taryba. Juolab kad pagal jo paties priimtą Laikinąją Konstituciją Steigiamasis Seimas ne tik buvo savo rankose monopolizavęs įstatymų leidžiamąją galią, bet ir prisièmęs griežtą vykdomosios valdžios kontrolę. Šikart nenorèta leisti, kad, net ir laikinai neposėdžiaujant Steigiamajam Seimui, valstybės valdymas netektų parlamentinès drausmės garanto.

Steigiamajam Seimui pavaduoti visai netiko vadovaujanti jo institucija - Prezidiumas, nes jam, remiantis laikinuoju Steigiamojo Seimo statutu $^{11}$, buvo pavestas tik bendras vadovavimas Seimo darbui. Savarankiškai Prezidiumas negalejjo atlikti jokių Seimo funkcijų, be to, jame tebuvo atstovaujamos įtakingiausiosios parlamentinès frakcijos, todèl jo sudètis buvo „mažiau ar daugiau vienašališka"12.

Taip pat atsisakyta minties laikinai patikèti valdžią kitai nuolat veikiančiai Steigiamojo Seimo institucijai - Seniūnų sueigai, kuri, remiantis tuo pačiu Steigiamojo Seimo statutu, buvo sudaryta iš visų frakcijų atstovų, stambiosioms frakcijoms turint po atstovą nuo kiekvienos dešimties savo narių, ir iš Steigiamojo Seimo Prezidiumo ${ }^{13}$. Nors Seniūnų sueigai 1920 m. rugpjūčio 13 d. isstatymu ${ }^{14}$ specialiai buvo numatyta galimybè pavaduoti Steigiamojo Seimo pilnati per darbo pertraukas, o pavaduojant - naudotis visomis jo turimomis Vyriausybès veiklos priežiūros priemonėmis, išskyrus interpeliacijos teisę, nežinant, kiek ilgai Steigiamasis Seimas negalès būti sušauktas, Seniūnų sueiga jo pavadavimui taip pat netiko. Žinoma, tai lèmè ne tik ne visos parlamentinès valdymo kontrolès priemonès, bet ir tai, kad neturèta įstatymų leidybos galių.

Teko ieškoti kitokio sprendimo.

${ }^{11}$ Lietuvos Steigiamojo Seimo statutas. Vyriausybès žinios (toliau - VŽ). 1921, Nr. 71635.

12 [Römeris] Rèmeris, M. Lietuvos konstitucinès teisès paskaitos. Vilnius: Mintis, 1990, p. 113.

13 Lietuvos Steigiamojo Seimo statutas. VŽ. 1921, Nr. 71-635.

${ }^{14}$ İstatymas dèl Steigiamojo Seimo Seniūnų sueigos teisès prižiūrèti įstatymo vykdymo. $L V Z ̌$. 1920 , Nr. 45-457. 


\section{Mažojo Seimo organizacijos ir veiklos teisinis reglamentavimas}

Ministrų kabineto spalio $20 \mathrm{~d}$. posėdyje Ministras Pirmininkas Kazys Grinius Vyriausybę informavo, kad vykdomosios valdžios „darbo palengvinimui“ Steigiamasis Seimas numatantis išsiskirstyti, savo vietoje palikdamas septynių narių „direktoriumą“. Užsiminta, jog tam pačiam tikslui svarstoma galimybè ir iš Kabineto sudèties išskirti mažąji kabinetą „skubiems klausimams rišti“"15. Ir jau spalio $22 \mathrm{~d}$. vykusiame 54 posėdyje Steigiamasis Seimas, apsvarstęs ir prièmęs Nepaprastos Valstybès Iždo paskolos krašto gynimo reikalams ịstatymą, dienos viduryje laikinai pertraukè darbą, o po šešeto valandų jị atnaujinęs, èmèsi svarstyti tos dienos posèdžio darbotvarkèje nenumatytą klausimą dèl Mažojo Seimo.

Posėdžiui pirmininkavęs Steigiamojo Seimo Pirmininkas Aleksandras Stulginskis suteikė žodị krikščionių demokratų bloko atstovui Mykolui Krupavičiui, kuris, motyvuodamas vykstančia lenkų agresija, pasiūlè laikinai sumažinti Steigiamojo Seimo sudètí, išsaugant jai visus reikiamus igaliojimus įstatymų leidybos ir Vyriausybės priežiūros sferose, išskyrus sutarčių su svetimomis valstybemis ratifikavimą. Pasiūlymą jis motyvavo pirmiausia tuo, kad pagrindinis Steigiamojo Seimo uždavinys esąs Konstitucijos ir žemès reformos parengimas, tačiau praktiškai pastaruoju metu jam daugiausia tenka rūpintis kitais aktualiais krašto reikalais; antra, dèl kraštui iškilusio pavojaus reikia geriau koordinuoti valdžios institucijų darbą, rodyti didesnị lankstumą ir veiklumą darbe. Jo žodžiais tariant, laikinai tapę nereikalingi Steigiamojo Seimo atstovai turètų pasklisti po kraštą ir ten organizuoti žmones valstybès gynimui arba bent teikti jiems teisingą informaciją apie esamą padètí ${ }^{16}$. Sykiu prelegentas referavo atitinkamo įstatymo projektą.

15 Ministrų Kabineto 19201020 posèdžio protokolas. Lietuvos centrinis valstybès archyvas (toliau - LCVA). F. 923, ap. 1, b. 86, lap. 316.

16 Steigiamojo Seimo darbai. I sesija. Sąs. 11 (1921), posèd. 54 (1920, spalio 22), p. 519. 
Teigiama, kad krikščionių demokratų bloko lyderio Steigiamajam Seimui išsakytas pasiūlymas prieš tai buvęs derintas su valstiečių liaudininkų bloko atstovais ${ }^{17}$. Tačiau iš Steigiamojo Seimo posèdžio stenogramos aiškejja apie projekto rengimą vienoje Seimo pakomisių. Tai leidžia manyti, kad jis nebuvo tik dviejų, nors ir pagrindinių, Steigiamojo Seimo blokų susitarimo rezultatas.

Debatuose dèl pasiūlymo kalbẻjo dešimt Steigiamojo Seimo atstovų, priklausiusių įvairioms frakcijoms. Iš pasisakiusiųjų tik socialdemokratai Kazys Venclauskis ir Jeronimas Plečkaitis išreiške savo frakcijos susirūpinimą dèl, jų manymu, diktatūrinio pasiūlymo pobūdžio ir perteikè nuomonę, kad visos Steigiamojo Seimo sudèties nutarimai tarp gyventojų turètų didesnį autoritetą; frakcija mananti, esą ,negalima mažai žmonių grupei perduoti Steigiamojo Seimo teises“. Prieštaraudami dèl naujosios institucijos steigimo, šie kalbètojai pritarè siūlymui skelbti Steigiamojo Seimo pilnaties darbo pertrauką, bet manė esant tikslinga palikti dirbti esamas komisijas, o įstatymų vykdymo priežiūrą pavesti Seniūnų sueigai.

Kiti kalbėjusieji - Vladas Lašas, Kazys Zubauskas, Oskaras Biuchleris, Antanas Tumėnas, Albinas Rimka, Jurgis Žitinevičius, Kazys Ambrazaitis, Vytautas Bičiūnas - iš esmès pritare Mykolo Krupavičiaus išsakytai Mažojo Seimo idejjai ir jo pristatytam įstatymo projektui ${ }^{18}$.

Teisiniu požiūriu Steigiamasis Seimas, būdamas konstitucinis suvereninès galios reiškejjas, galëjo visiškai nevaržomai kurti naujas institucijas ir joms pavesti tam tikras savo funkcijas. Ir nors galiojančios 1920 metų Laikinosios Konstitucijos ketvirtasis straipsnis Steigiamojo Seimo galias fokusavo ị ịstatymų leidybą, sutarčių su kitomis valstybėmis ratifikavimą, valstybès biudžeto tvirtinimą ir įstatymų vykdy-

${ }^{17}$ Viliamas, V. Lietuvos Seimai ir jų grupinė diferenciacija. Tèvynés sargas. 1954, Nr. $1(11)$, p. 84.

18 Steigiamojo Seimo darbai. I sesija. Sąs. 11 (1921), posèd. 54 (1920, spalio 22), p. 519-527. 
mo priežiūrą, nenumatydamas galimybių šias teises kam nors pavesti, vien paminètų teisių siūlomame ịstatymo projekte ịvardijimas, M. Romerio teigimu, turèjęs reikšti ne daugiau kaip paties Steigiamojo Seimo susivaržymo demonstravimą, nuo kurio „suverenas visuomet savo suverenine galia gali ir pasiliuosuoti“"19.

Čia pat skubos tvarka paeiliui visais trimis skaitymais buvo priimtas nedidelès apimties, sudarytas vos iš penkių paragrafų, Mažojo Seimo sudarymo įstatymas ${ }^{20}$.

Nustatyta (2 paragrafas), kad Mažojo Seimo sudètyje bus septyni žmonès - Steigiamojo Seimo Pirmininkas ir šeši Steigiamojo Seimo renkami nariai. Siekiant, kad Mažojo Seimo darbas neliktų paralyžiuotas, jeigu dèl kokių nors priežasčių išrinktas narys pasitrauktų iš jo sudèties, ịstatyme (2 paragrafo pastaba) numatyta išrinkti dar po kandidatą kiekvienam nariui pavaduoti.

Skelbta, kad Mažasis Seimas nebūsiąs Valstybės Taryba ar antraisiais parlamento rūmais, o dirbsiąs, išskyrus nedideles išimtis, tą patị darbą, kurị dirba visos sudèties Steigiamasis Seimas ${ }^{21}$.

Du įstatymo straipsniai nusake Mažojo Seimo kompetenciją - dalykus iš Steigiamojo Seimo galių katalogo, kuriuos jis laikè galimais ir reikalingais pavesti kuriamai institucijai - beveik visus ipprastinius parlamentinès institucijos, kurios darbą lygiagrečiai su steigiamosiomis funkcijomis atlikinèjo Steigiamasis Seimas, galių komponentus.

Istatymas, ịteisindamas Mažojo Seimo galią ịstatymų leidyboje, jam suteikè teisę leisti ne ịstatymus apskritai, o tik „einamuosius“ įstatymus. Ši nuostata pirmiausia reiškè, kad Steigiamasis Seimas, leisdamas Mažajam Seimui pakeisti save, net laikinai neatsisake ypatingų savo teisių ir neskyrė tik jam priklausančių steigiamųjų galių, t. y. tik pačiam

${ }^{19}$ [Römeris] Rèmeris, M. Lietuvos konstitucinès teisès paskaitos. Vilnius: Mintis, 1990, p. 95.

20 Steigiamojo Seimo darbai. I sesija. Sąs. 11 (1921), posèd. 54 (1920, spalio 22), p. 527; Mažojo Seimo sudarymo įstatymas. VŽ. 1920, Nr. 50-491.

${ }^{21}$ Mūsų padètis ir Seimas. Laisvè. 1920, spalio 28 (Nr. 222). 
Steigiamajam Seimui patikèto valstybès pagrindų nustatymo ir konstitucinio įtvirtinimo. Antra, M. Romerio manymu, ịstatyme vartojama „einamųjų“ i̊statymų sąvoka yra siauresnè už įstatymams, iš kurių tereikalaujama neprieštarauti galiojančiai konstitucijai, taikytiną „paprastųjų“ isstatymų sąvoką. Todèl Mažajam Seimui, teisininko teigimu, taip pat nebuvo suteikta galia leisti organiškus stambios reformos ịstatymus, pavyzdžiui, tokius kaip skirtus žemès reformai ${ }^{22}$. Ir nors, pasak M. Krupavičiaus, „einamuosius įstatymus“ esą "galima suprasti kuo plačiausiai, neišskiriant ir pamatinių “23, iš tikrųjų Mažojo Seimo įstatymų leidžiamoji galia buvo ribota eilinių dienos ịstatymų ${ }^{24}, \mathfrak{i}$ kuriuos, žinoma, neįejo konstituciniai ir su žemès reforma susiję ịstatymai ${ }^{25}$.

İstatymas nesuteikè Mažajam Seimui valstybès biudžeto tvirtinimo galių, bet numatė jam kreditų tvirtinimo, kaip laikinos priemonès, kurios tektų imtis nesant Steigiamojo Seimo patvirtinto valstybės biudžeto, teisę.

Pagaliau įstatymas fiksavo Mažojo Seimo įstatymų vykdymo priežiūros teisę: jame nurodyta, jog Steigiamojo Seimo pertraukos laikotarpiu Ministrų kabinetas ir valstybès kontrolierius už savo darbą atsako Mažajam Seimui ir, šiam išreiškus nepasitikejjimą, atsistatydina. Vadinasi, Vyriausybės kontrolès požiūriu Mažajam Seimui taip pat buvo suteikta visa Steigiamojo Seimo galia.

Tam tikrą sąmyši kèlè tik tarptautinių sutarčių ratifikavimo teisė, i̊sakmiai nurodyta Steigiamojo Seimo galių kataloge. Svarstant Mažojo Seimo įstatymo projektą buvo pasiūlyta nustatyti, jog „išimtinais atsitikimais“, Steigiamajam Seimui negalint susirinkti, Mažasis Seimas turès teisę ir ị kitus jo kompetencijai priklausančius dalykus, numatytus ketvirtajame Laikinosios Konstitucijos straipsnyje (jau minėta, jog jame tarp Steigiamojo Seimo prerogatyvų, dabar paverčiamų ir Mažo-

${ }^{22}$ Pauliukonis, P. Lietuvos valstybès pagrindus tiesiant. Aidai. 1970, Nr. 5, p. 115-116.

${ }_{23}$ Steigiamojo Seimo darbai. I sesija. Sąs. 11 (1921), posèd. 54 (1920, spalio 22), p. 525.

${ }^{24}$ Mūsų padètis ir Seimas. Laisvè. 1920, spalio 28 (Nr. 222).

25 Mažojo Seimo darbuotè. Laisvé. 1920, gruodžio 3 (Nr. 3). 
jo Seimo kompetencijos dalyku, nurodomas dar ir sutarčių su kitomis valstybèmis ratifikavimas), bet ši nuostata buvo atmesta, motyvuojant ìstatyme formuluojamos Mažojo Seimo kompetencijos pakankamu$\mathrm{mu}^{26}$. Analizuodamas Mažojo Seimo sudarymo įstatymą, M. Romeris išsakè nuomonę (greičiau išreiškiančią teiginị, o ne abejonę), kad jame esančius igaliojimus „leidžia einamuosius ịstatymus“ ir „prižiūri ịstatymų vykdymą“ vargu ar galima laikyti apimančiais ir tarptautinių sutarčių ratifikavimo teisę ${ }^{27}$. Neigiamas požiūris ị sutarčių su svetimomis valstybėmis ratifikavimo teisès Mažajam Seimui suteikimą atsispindi ir įstatymo referento M. Krupavičiaus žodžiuose pristatant įstatymo projektą. Tai, kad Mažajam Seimui teisè ratifikuoti tarptautines sutartis neduota, patvirtino ir to meto krikščionių demokratų spauda ${ }^{28}$.

Nedidelę îstatymo preambulę sudarè nuostata dèl jo įsigaliojimo laiko: nurodoma, kad šis įstatymas veikia Steigiamajam Seimui „darant nuo šios dienos sesijos pertrauką“"

Mažojo Seimo sudarymo įstatymas pabrèžè, kad naujoji institucija steigiama tiktai šiai Steigiamojo Seimo pertraukai (1 paragrafas), vadinasi, ji buvo numatyta tik kaip epizodinè institucija, kuri, Steigiamajam Seimui vèl susirinkus, turèjo iš karto būti likviduota. Pagaliau, nepaskyrus konkrečios sesijos atnaujinimo datos, Steigiamajam Seimui priimant Mažojo Seimo įstatymą ir laikinai nutraukiant savo sesiją, svarbią reikšmę igijo îstatymo nuostata dèl teisès inicijuoti sesijos atnaujinimą, kartu užbaigiant Mažojo Seimo įstatymo galiojimą. Tokia teisė buvo patikèta pačiam Mažajam Seimui ir jo pirmininkui, taip pat ketvirtadaliui Steigiamojo Seimo atstovų (5 paragrafas).

Jau tą patị vakarą, prièmus Mažojo Seimo sudarymo ịstatymą, Steigiamasis Seimas išrinko naujosios institucijos sudètị.

${ }^{26}$ Steigiamojo Seimo darbai. I sesija. Sąs. 11 (1921), posèd. 54 (1920, spalio 22), p. 519 , 525-526.

27 [Römeris] Rèmeris, M. Lietuvos konstitucinès teisès paskaitos. Vilnius: Mintis, 1990, p. 116.

${ }^{28}$ Mūsų padètis ir Seimas. Laisvè. 1920, spalio 28 (Nr. 222). 
Nors ịstatymas nereikalavo Mažajame Seime išlaikyti tarpfrakcines Steigiamojo Seimo proporcijas, kaip, pavyzdžiui, formuojant Seniūnų sueigą, ì ši politiškai jautrų dalyką visiškai atsižvelgta: nuo Steigiamajame Seime absoliučią atstovų daugumą turẻjusio krikščionių demokratų bloko ị Mažąj Seimą išrinkti du atstovai (trečia vieta šiam gausiausiam blokui teko dèl jam atstovavusio Steigiamojo Seimo Pirmininko), dvi vietas taip pat gavo antras pagal dydị valstiečių liaudininkų blokas. Socialdemokratai, pasisakę prieš Mažojo Seimo idejją, bet vèliau pareiškę frakcijos sutikimą ịeiti ị kuriamą instituciją, ir tautinès mažumos gavo po vieną vietą. Kartu su Steigiamojo Seimo Pirmininku A. Stulginskiu ị Mažojo Seimo sudètị išrinkti M. Krupavičius ir Antanas Tumėnas, V. Lašas ir Mykolas Sleževičius, K. Venclauskis ir Naftalis Fridmanas. Kandidatais ị jo narius tapo Eliziejus Draugelis, Juozas Vailokaitis, Jonas Kriščiūnas, Vladas Natkevičius, Steponas Kairys ir Maksas Soloveičikas ${ }^{29}$. Ši atsarga, beje, netrukus pasiteisino: i kitą veiklos barą perejjus ar susirgus M. Krupavičiui, M. Sleževičiui, V. Lašui, K. Venclauskiui, juos Mažajame Seime, išsaugodami buvusią tarpfrakcinę proporciją, įvairiu metu buvo pakeitę E. Draugelis, J. Kriščiūnas, S. Kairys ${ }^{30}$.

Steigiamasis Seimas išsiskirstė artejjant tos pačios dienos pusiaunakčiui ${ }^{31}$, tada niekam nežinant, kada ir kokiomis sąlygomis jis vèl galès susirinkti. Dalis jo atstovų (Jonas Galvydis-Bykauskas, Pulgis Lumbis, Antanas Matulaitis, Klemensas Vaitiekūnas ir kt.) išvyko ị frontą, kita dalis - i provinciją burti savanorių, padèti organizuoti šaulių būrius, informuoti žmones apie padėtị, rinkti kariuomenei maistą, šiltus drabužius. Kai kurie Steigiamojo Seimo atstovai stojo ị Vyriausybès i̊staigas arba liko prie Mažojo Seimo įstatymų projektams rengti.

${ }^{29}$ Steigiamojo Seimo darbai. I sesija. Sąs. 11 (1921), posèd. 54 (1920, spalio 22), p. 526-527.

30 Mažojo Seimo darbuotè. Laisvè. 1920, gruodžio 3 (Nr. 3); Mažasis Seimas. Lietuva. 1920, spalio 31 (Nr. 238).

31 Steigiamojo Seimo darbai. I sesija. Sąs. 11 (1921), posèd. 54 (1920, spalio 22), p. 527. 
Mažasis Seimas buvo savotiška naujovè mūsų jaunos valstybès parlamentiniame gyvenime ${ }^{32}$, nors pasaulineje konstitucineje praktikoje siauresnès sudèties parlamentinès institucijos sudarymas nebuvo visai naujas ir negirdètas ${ }^{33}$.

Mažojo Seimo sudarymo įstatymas buvo pasirašytas $1920 \mathrm{~m}$. spalio $25 \mathrm{~d}$. ir „Vyriausybès žiniose“ paskelbtas spalio $29 \mathrm{~d}$.

\section{Mažojo Seimo veikla ir reikšmẻ}

I pirmąji posėdi Mažasis Seimas susirinko jau spalio 23 d. - kitą dieną po Steigiamojo Seimo išsiskirstymo. Tądien Mažojo Seimo sekretoriumi ir laikinuoju Pirmininko pavaduotoju išrinktas V. Natkevičius, sudaryta komisija Mažojo Seimo statutui parengti (A. Tumènas ir N. Fridmanas). Lapkričio 25 d. posėdyje nuolatiniais Pirmininko pavaduotojais išrinkti M. Sleževičius ir V. Lašas ${ }^{34}$.

Mažojo Seimo dirbta labai intensyviai. Pasak spaudos pranešimų, pirmajame jo posėdyje nusistatyta posėdžiauti kasdien, išskyrus sekmadienius ${ }^{35}$, tačiau netrukus nutarta tenkintis trimis posèdžiais per savaitę, kartu numatant galimybę prireikus šaukti extra posėdžius ${ }^{36}$. Realiai per beveik tris veiklos mènesius, tiksliau - per 86 dienas, Mažasis Seimas buvo susirinkęs ì 45 posėdžius ${ }^{37}$. Veikdamas kaip parlamentine įstaiga, jis vykde praktiškai visas jos funkcijas.

Istatymų leidybos srityje iš pradžių tikètasi naudotis Steigiamojo Seimo komisijų ìdirbiu arba kviestis tų komisijų narius ekspertais.

32 Raulinaitis, P.V. Parlamentarizmas: istoriniai-teoretiniai parlamentinès tvarkos bruožai. Klaipėda, 1925, p. 53.

33 [Römeris] Rèmeris, M. Lietuvos konstitucinès teisès paskaitos. Vilnius: Mintis, 1990, p. 114.

${ }^{34}$ Mažasis Seimas. Lietuva. 1920, lapkričio 31 (Nr. 263).

35 Mažasis Seimas. Lietuva. 1920, lapkričio 26 (Nr. 233); Iš Mažojo Seimo. Laisvé. 1920, spalio 29 (Nr. 225).

36 Mažasis Seimas. Lietuva. 1920, lapkričio 31 (Nr. 263).

37 Steigiamojo Seimo darbai. I sesija. Sąs. 12 (1921), posèd. 55 (1921, sausio 17), p. 529. 
Šios komisijos toliau turèjo dirbti Steigiamojo Seimo statuto nustatyta tvarka ${ }^{38}$, o pagrindinès - Konstitucijos ir Žemès reformos - nuolat. Per visą Mažojo Seimo veiklos laikotarpi po vieną du kartus Steigiamojo Seimo komisijų (Darbo, socialinès apsaugos ir sveikatos, Skundų ir tardymo, Ekonominès, Mandatų ir peticijų, Žemès reformos) nariai i posėdžius buvo kviečiami per laikraščius ${ }^{39}$. Tačiau, pasak opozicinės spaudos, Konstitucijos komisijoje darbas nejęs, Žemès reformos komisija buvo iškrikusi, o apie kitas - „sunku bekalbėti“40. Nepaisant to, įstatymų leidybos darbas Mažajame Seime vyko nuolat, laikantis tradicinès trijų skaitymų procedūros. Iš viso, A. Stulginskio pateiktais duomenimis, jis spejo apsvarstyti 51 ịstatymo projektą, iš kurių 25 buvo priimti ${ }^{41}$.

Iš tiesų ịstatymų su tiesiogine nuoroda apie jų prièmimą Mažajame Seime „Vyriausybès žiniose“ buvo paskelbta devyniolika. Be to, 1920 m. „Vyriausybės žinių“ 52 numeryje yra trys ịstatymai - Lietuvos muitinių tarifo, „Istatymo apie laikiną prekybos suvaržymą Lietuvos pasieniuose" pakeitimo ir papildymo bei Karo įstatymų XXII knygos pakeitimų ir papildymų, kurie nurodomi kaip priimti Steigiamajame Seime atitinkamai 1920 m. spalio 30, lapkričio 3 ir lapkričio 4 dienomis, t. y. tuomet, kai Steigiamasis Seimas, užleidęs savo vietą Mažajam Seimui, pats faktiškai nedirbo (po 54 posėdžio, ivvykusio $1920 \mathrm{~m}$. spalio $22 \mathrm{~d}$., 55-asis surengtas $1921 \mathrm{~m}$. sausio $17 \mathrm{~d}$.). Iš informacijos spaudoje aiškèja, jog šių trijų įstatymų projektai spalio $26 \mathrm{~d}$. buvo pateikti Mažojo Seimo posėdžiui ${ }^{42}$, ir du iš jų - apie prekybos suvaržymą pasieniuose bei Karo ịstatymų XXII knygos pakeitimus - priimti

${ }^{38}$ Iš Mažojo Seimo. Laisvè. 1920, spalio 29 (Nr. 225).

39 Iš Steigiamojo Seimo kronikos. Lietuvis. 1920, lapkričio 16 (Nr. 250); Iš Steigiamojo Seimo. Lietuva. 1920, lapkričio 31 (Nr. 263); Iš Steigiamojo Seimo kronikos. Lietuva. 1920, gruodžio 19 (Nr. 278); Iš Steigiamojo Seimo kronikos. Lietuva. 1921, sausio 5 (Nr. 3).

40 Pagalios šaukiamas Seimas. Socialdemokratas. 1921, sausio 6 (Nr. 1).

${ }^{41}$ Steigiamojo Seimo darbai. I sesija. Sąs. 12 (1921), posėd. 55 (1921, sausio 17), p. 529.

42 Iš Mažojo Seimo. Laisve. 1920, spalio 29 (Nr. 225). 
„Vyriausybės žiniose“ nurodytomis dienomis ${ }^{43}$. Tik informacijoje apie Mažojo Seimo spalio $30 \mathrm{~d}$. posėdi neužsimenama apie Lietuvos muitinių tarifus ${ }^{44}$, bet prieš tai buvo skelbta ir apie jų prièmimą pirmuoju skaitymu spalio $27 \mathrm{~d} .{ }^{45}$ bei antruoju - spalio $28 \mathrm{~d} .{ }^{46}$ Tad galima manyti, kad spaudos informacija šiuo atveju buvo tiesiog ne visa. Taigi esama pakankamo pagrindo teigti, jog visi šie įstatymai nurodytomis dienomis iš tiesų buvo priimti, bet ne Steigiamajame, o Mažajame Seime, ir tapo pirmaisiais oficialiai paskelbtais pastarojo ịstatymais, o juos skelbiant tiesiog padaryta klaida arba, galimas daiktas, pradžioje apskritai rengtasi juos visus, priimtus Mažajame Seime, oficialiai kildinti iš paties Steigiamojo Seimo, kaip vienintelio konstitucinio įstatymų leidejo.

Natūraliai kylantis klausimas, kodèl „Vyriausybès žiniose“ nèra oficialiai paskelbtų likusių trijų Mažojo Seimo priimtų ịstatymų, deja, lieka be atsakymo. Juolab kad tuomet galiojusi 1920 m. Laikinoji Lietuvos Valstybès Konstitucija, pavesdama Respublikos Prezidentui skelbti Steigiamojo Seimo įstatymus (8 str.), veto teisès jam nebuvo suteikusi $^{47}$.

İsigalioję Mažojo Seimo priimti ịstatymai pagal turinị susiję su ìvairiomis valstybès ir visuomenès gyvenimo sritimis. Su nepaprastosiomis karo sąlygomis iš „Vyriausybès žiniose“ paskelbtų Mažojo Seimo priimtų ístatymų tiesiogiai buvo susijusi tik nedidelè jų dalis. Galima būtų pažymėti tris spalio $27 \mathrm{~d}$. priimtus Baudžiamojo statuto pakeitimų ir papildymų ịstatymus, nustačiusius bausmes už karinių medžiagų ir įrengimų grobimą, dezertyravimą bei kai kuriuos kitus nusikaltimus, padarytus karo metu (VŽ, 1920, Nr. 54-510, 511, 512). Šiai grupei gali būti priskirti: lapkričio $20 \mathrm{~d}$. Savivaldybių ịstatymo

${ }_{43}$ Mažasis Seimas. Lietuva. 1920, lapkričio 5 (Nr. 241).

${ }^{44}$ Mažasis Seimas. Lietuva. 1920, spalio 30 (Nr. 237).

${ }^{45}$ Iš Mažojo Seimo. Laisvè. 1920, spalio 29 (Nr. 225).

${ }^{46}$ Mažasis Seimas. Lietuva. 1920, spalio 29 (Nr. 236).

47 [Römeris] Rèmeris, M. Lietuvos konstitucinès teisès paskaitos. Vilnius: Mintis, 1990, p. 95. 
pakeitimo įstatymas, pusmečiui pratęsęs gruodžio mėnesị turèjusius baigtis valsčių ir apskričių savivaldybių igaliojimus, bei gruodžio 21 d. Pasų ịstatų pakeitimo įstatymas, iki $1921 \mathrm{~m}$. gegužès $1 \mathrm{~d}$. atidèjęs kiek anksčiau buvusị nustatytą terminą gyventojams apsirūpinti pasais (VŽ, 1921, Nr. 55-525, 522), nes tai atlikti laiku galejo trukdyti nepaprastosios aplinkybės, arba gruodžio $30 \mathrm{~d}$. Valstybės iždo paskolos lakštų ịstatymo pakeitimas (VŽ, 1921, Nr. 55-523), nuo ketverių iki aštuonerių metų pratęsęs šių paskolos lakštų galiojimo laiką, bei 1921 m. sausio 7 d. Rekvizicijų ir nepaprastųjų mokesnių ịstatymas (VŽ, 1921, Nr. 56-535).

Vis delto dauguma ịstatymų buvo eiliniai, nesietini su nepaprastosiomis aplinkybėmis, reglamentavę ūkinius ir ịvairius kitokius reikalus. Tarp Mažojo Seimo priimtų ịstatymų buvo $1920 \mathrm{~m}$. gruodžio 21 d. Valstybinio apdraudimo įstaigos ịstatai (VŽ, 1921, Nr. 56-528) ir gruodžio 6 d. İstatymas sąlygoms naudotis telefono tinklu (VŽ, 1920, Nr. 55-521), 1921 m. sausio 15 d. Lietuvos kredito banko (VŽ, 1921, Nr. 63-571) ir Lietuvos tarptautinio banko (VŽ, 1921, Nr. 64-580) istatai bei kiti įstatymai.

Beje, kai kurių su krašto gynyba nieko bendra neturinčių ịstatymų leidimas Mažajame Seime, sudarytame karo aplinkybėmis ir, kai kurių manymu, igaliotame rūpintis tik krašto gynimo reikalais, buvo sulaukęs nepasitenkinimo, reikšto opozicinejje socialdemokratų spaudoje ${ }^{48}$.

Mažojo Seimo priimti ịstatymai baigti skelbti $1921 \mathrm{~m}$. balandžio 28 d. „Vyriausybès žinių“ numeryje.

Vyriausybès veiklos kontrolès srityje svarbiausiu Mažojo Seimo darbu tenka laikyti S. Kairio interpeliaciją krašto apsaugos ministrui dèl Širvintų kautynių epizodo, kai per fronto liniją prasilaužusi lenkų raitelių grupe vèliau užnugaryje kurị laiką terorizavo gyventojus ${ }^{49}$. Krašto apsaugos ministras K. Žukas primygtinai prašè Mažąji Seimą

${ }^{48}$ Mažasis Seimas. Socialdemokratas. 1920, gruodžio 9 (Nr. 32).

49 S. Kairio interpeliacijos Ministrų kabineto pirmininkui ir krašto apsaugos ministrui nuorašas. $L C V A$. F. 923 , ap. 1, b. 99, lap. 123. 
priimti interpeliaciją, tikèdamasis panaudoti svarstymą visuomenei informuoti apie ịsibrovèlių likvidavimą ir jai nuraminti ${ }^{50}$. Vis dèlto gruodžio $14 \mathrm{~d}$. ịvykęs svarstymas Mažajame Seime nepasitikèjimo ministru nepareiške $\dot{e}^{51}$.

Funkcionuojant Mažajam Seimui Vyriausybė ir konkretūs ministrai sulaukè tiek Mažojo Seimo, tiek ir ì ji nepatekusių Steigiamojo Seimo atstovų paklausimų ${ }^{52}$, dèl kurių gausos atsakymams buvo skirta nuolatinė savaitès diena ${ }^{53}$. Mažajame Seime 1920 m. spalio 25 d. išklausyta krašto apsaugos ministro informacija apie kariuomenès maitinimą, sanitarinę ir strateginę padètį ${ }^{54}$, lapkričio $8 \mathrm{~d}$. - iš Paryžiaus ir Londono sugrị̌žusio užsienio reikalų ministro pranešimas apie Lietuvos politinès padèties vertinimą užsienyje ${ }^{55}$. Lapkričio $15 \mathrm{~d}$. Mažajam Seimui atsiskaitė delegacija, kurią dèl prasidejusios lenkų invazijos spalio $1 \mathrm{~d}$. Steigiamasis Seimas išsiuntè $\mathfrak{i}$ užsieni ${ }^{56}$.

Atliktų darbų îvairumu ir apimtimi Mažasis Seimas nenusileido Steigiamojo Seimo pilnačiai. Tautos sutelktomis pastangomis $1920 \mathrm{~m}$. lapkričio 19 ir 21 d. pradžioje ties Širvintomis, o po to ties Giedraičiais Lietuvos kariuomenei pavyko laimèti lemiamas kautynes ir ne tik sustabdyti lenkų veržimąsi ị Lietuvą, bet ir sudaryti realią galimybę

${ }^{50}$ Mažasis Seimas. Lietuva. 1920, gruodžio 5 (Nr. 267); Mažasis Seimas. Laisve. 1920, gruodžio 16 (Nr. 13); Mažojo Seimo darbuotè. Laisvè. 1920, gruodžio 5 (Nr. 5).

${ }^{51}$ Krašto apsaugos ministro Žuko kalba Mažajame Seime gruodžio 14 d. Lietuva. 1920, gruodžio 16 (Nr. 275); Mažasis Seimas. Lietuva. 1920, gruodžio 15 (Nr. 274); Mažasis Seimas. Laisvè. 1920, gruodžio 17 (Nr. 14); Mažasis Seimas. Laisvè. 1920, gruodžio 18 (Nr. 15).

52 V. Bičiūno, K. Bielinio, N. Fridmano, V. Lašo, V. Mieleškos, P. Radzevičiaus, M. Sleževičiaus, A. Tumėno, B. Žygelio paklausimai. LCVA. F. 923, ap. 1, b. 99, lap. 108, 109, 106, 111, 115, 116, 118, 119, 126, 128-129, 131; b. 185, lap. 67, 68, 69, 70.

53 Steigiamojo Seimo raštinès 19201130 raštas Ministrų kabineto reikalų vedèjui. LCVA. F. 923, ap. 1, b. 100, lap. 205.

${ }^{54}$ Mažasis Seimas. Lietuva. 1920, spalio 26 (Nr. 233); Iš Mažojo Seimo. Laisvè. 1920, spalio 29 (Nr. 225).

55 Mažasis Seimas. Lietuva. 1920, lapkričio 10 (Nr. 245); Užsienio reikalų ministerio dr. Purickio pranešimas Mažajame Seime. Laisve. 1920, lapkričio 10 (Nr. 233).

56 Steigiamojo Seimo delegacija užsieny. Lietuva. 1920, lapkričio 20 (Nr. 254). 
pačiai žengti Vilniaus link. Tik ịsikišus Tautų Sąjungos komisijai, Lietuvos kariuomenès žygis sustojo ir tarp kariaujančių šalių nustatyta neutrali zona, o Vilniaus bylą Lietuvos Vyriausybè patikèjo Tautų Sąjungai. Valstybei kilęs pavojus nuslinko, krizė tam kartui baigèsi. Vèl atsirado sąlygos susirinkti Steigiamajam Seimui, todèl $1921 \mathrm{~m}$. sausio $8 \mathrm{~d}$. Steigiamojo Seimo Prezidiumas prièmė nutarimą sausio $17 \mathrm{~d}$. skirti pirmąji po pertraukos Steigiamojo Seimo posėdị ${ }^{57}$.

Steigiamojo Seimo darbo atnaujinimas pažymètas kaip didelè šventè. Posèdyje dalyvavo visa Ministrų kabineto sudètis, svetimų valstybių atstovai, daugybė svečių ${ }^{58}$.

Posèdị atidarė Respublikos Prezidento pareigas einantis Steigiamojo Seimo Pirmininkas A. Stulginskis. Jam pasiūlius, susirinkusieji tylos minute pagerbẻ kritusiųjų už Tẻvynès laisvę, tarp jų ir į Tẻvynès gynèjų eiles stojusio Steigiamojo Seimo nario karininko Antano Matulaičio, atminimą.

Buvusią Steigiamojo Seimo darbo pertrauką A. Stulginskis ịvertino $^{59}$ svariu jo atstovų indèliu ị visų tautos pajègų susitelkimą, neišvengiamu siekiant laimèti žūtbūtinę kovą. Salei pritariamai plojant jis pabrèžè, kad praejusios dienos dar kartą visus ịtikino tautos galybę glūdint jos vienybèje, kad sunkią valandą ji galinti pasikliauti tiktai savo jègomis.

Mažojo Seimo veiklos laikotarpis baigèsi. Net ir neilgai funkcionavęs, pasak M. Romerio, jis anuomet „tvirtai įsibrovè ị konstitucinę valstybès valdžios organizaciją“60.

57 Iš Steigiamojo Seimo kronikos. Lietuva. 1921, sausio13 (Nr. 9).

58 Steigiamasis Seimas. Lietuva. 1921, sausio 19 (Nr. 14).

59 Steigiamojo Seimo darbai. I sesija. Sąs. 12 (1921), posėd. 55 (1921, sausio 17), p. 530.

${ }^{60}$ [Römeris] Rėmeris, M. Lietuvos konstitucinès teisés paskaitos. Vilnius: Mintis, 1990, p. 115. 


\section{Išvados}

Susidariusiomis politinėmis aplinkybėmis Steigiamojo Seimo isteigta siauros sudèties institucija, kuriai laikinai buvo pavesta einamoji jo veikla, buvo pagrịsta. Mažojo Seimo ịstatymo prièmimas, šios institucijos įsteigimas ir veikla sudare sąlygas nesutrikdyti Steigiamojo Seimo, pagrindinę laiko dalị, rengiant valstybès pagrindinius įstatymus, skyrusio einamajai parlamentinei veiklai, darbo ritmo. Kartu tai leido ị Steigiamąjị Seimą išrinktiems autoritetingiausiems visuomenès nariams ịsijungti ị tiesioginę veiklą mobilizuojant krašto pajègas kovai prieš agresorių. Mažojo Seimo sumanymas ir jo igyvendinimas pademonstravo politinị Steigiamojo Seimo lankstumą, jo atstovų norą ir gebejjimą savo įsitikinimus ir valią paskirti bendriems valstybès interesams, mokejjimą sutartinai ieškoti tinkamų nestandartinių sprendimų, kurie leido valstybei ịveikti sunkiausias negandas. 


\title{
THE LITTLE DIET IN THE HISTORY OF LITHUANIAN PARLIAMENT
}

\author{
Mindaugas Maksimaitis
}

\section{Summary}

Keywords: parliamentary; Constituent Assembly of Lithuania; The Little Diet.

The article describes historical and legal prerequisites for the origination of the Little Diet of Lithuania, which makes a significant episode in the history of Lithuanian parliamentarism. The article analyses the origin, the formation and the activity of the institution.

After the country was exposed to the danger of the Polish aggression causing an actual threat to the State of Lithuania the Constituent Assembly decided to temporarily terminate its activities. Therefore the Little Diet was established on 22 October 1920 for the period of three months (till 17 January 1921) to substitute for the Constituent Assembly. This temporary institution was established solely to fill in the break of the Constituent Assembly for the period of almost three months, since in the face of a threat for the country the functioning of the State powers had to be coordinated better, to operate more flexibly and actively.

The special law by the Constituent Assembly was adopted under which the Little Diet was authorized with nearly full juris- diction, except for the constituent powers in defining the basics of the state and the ratification of international agreements. In setting up the Little Diet which consisted of seven members, the interfraction proportion of the Constituent Assembly was preserved.

During the period of activity of the Little Diet forty five sittings were held, fifty one bills were submitted for consideration and twenty five laws were adopted. One interpellation was submitted for consideration, the answers of ministers to the inquiries given by members of the Constituent Assembly were auditioned.

The incorporation and activity of the Little Diet formed favorable circumstances for authoritative members of the Constituent Assembly to join the direct activities of mobilizing country's resources to fight against the aggressor. It helped avoid interruptions of the activities of the General Assembly which used most of its time for parliamentary activities in parallel to legislative efforts.

Iteikta 2014 m. sausio $22 d$. 